\title{
Difteri pada Anak
}

Edi Hartoyo

Bagian Ilmu Kesehatan Anak Fakultas Kedokteran Universitas Lambungmangkurat/RSUD Ulin, Banjarmasin

Abstrak

Difteri adalah infeksi akut yang disebabkan oleh kuman Corynebacterium diptheriae toksigenik dapat menyerang saluran nafas, kulit, mata, dan organ lain. Penyakit ini ditandai dengan demam, malaise, batuk, nyeri menelan dan pada pemeriksaan terdapat pseudomembran kas. Penyakit ini ditularkan melalui kontak atau droplet, dan diagnosis pasti ditegakan berdasarkan gejala klinis dan kultur atau PCR. Terdapat 939 kasus di 30 provinsi di Indonesia dengan angka kematian 44 kasus dan case fatality rate 4,7\% selama KLB tahun 2017. Penyakit ini dapat dicegah dengan imunisasi. Sari Pediatri 2018;19(5):300-6

Kata kunci: difteri, gejala klinis , terapi dan vaksinasi

\section{Diphtheria in Children}

Edi Hartoyo

Abstract

Diphtheria is an acute infection caused by the bacteria Corynebacterium toxigenic diptheriae can invade the respiratory tract, skin, eyes and other organs. The clinical symptom fever, malaise, cough, sore throat and on examination there is pseudomembran spesific. The disease is transmitted by contact or droplet, and a definite diagnosis is established based on clinical symptom and culture symptoms or PCR. Visible 939 cases in 30 provinces in Indonesia with 44 deaths and case fatality rate 4.7\% during outbreaks in 2017. This disease can be prevented by immunization. Sari Pediatri 2018;19(5):300-6

Keywords: diphtheria, clinical symptoms, therapy and vaccination

Alamat korespondensi: DR. Dr. Edi Hartoyo, SpA(K). Departemen Illmu Kesehatan Anak Universitas Lambungmangkurat, Banjarmasin, Kalimantan Selatan. Email: edihartoyo@yahoo.com 


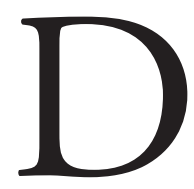

ifteri adalah penyakit akut yang disebabkan oleh Corynebacterium diphtheria, suatu bakteri Gram positif fakultatif anaerob. Penyakit ini ditandai dengan sakit tenggorokan, demam, malaise dan pada pemeriksaan ditemukan pseudomembran pada tonsil, faring, dan / atau rongga hidung. ${ }^{1}$ Difteri adalah penyakit yang ditularkan melalui kontak langsung atau droplet dari penderita. Pemeriksaan khas menunjukkan pseudomembran tampak kotor dan berwarna putih keabuan yang dapat menyebabkan penyumbatan karena peradangan tonsil dan meluas ke struktur yang berdekatan sehingga dapat menyebabkan bull neck. Membran mudah berdarah apabila dilakukan pengangkatan. ${ }^{1,2}$

Diagnosis cepat harus segera dilakukan berdasarkan gejala klinis, laboratorium (swab tenggorok, kultur, atau PCR) untuk penanganan lebih awal. Tata laksana terdiri dari penggunaan antitoksin spesifik dan eliminasi organisme penyebab.

Komplikasi dari difteri dapat menyebabkan obstruksi jalan napas, miokarditis, paralisis otot palatum, otitis media dan juga dapat menyebar ke paru-paru menyebabkan pneumonia. Pencegahan dengan melakukan imunisasi, pengobatan karier, dan penggunaan APD. ${ }^{3,5,9}$

\section{Epidemiologi}

Penularan disebarkan melalui droplet, kontak langsung dengan sekresi saluran napas penderita atau dari penderita karier. Pada daerah endemis, 3\%-5\% orang sehat bisa sebagai pembawa kuman difteri toksigenik. Kuman C. diptheriae dapat bertahan hidup dalam debu atau udara luar sampai dengan 6 bulan. $^{2}$

Pada tahun 2014, jumlah kasus difteri 296 kasus dengan jumlah kasus meninggal 16 orang dengan CFR difteri $4 \%$. Dari 22 provinsi yang melaporkan adanya kasus difteri, provinsi tertinggi terjadi di Provinsi Jawa Timur, yaitu 295 kasus yang berkonstribusi sebesar 74\%. Dari total kasus tersebut, 37\% tidak mendapakan vaksin campak. Sementara pada tahun 2015 terdapat 252 kasus difteri dengan 5 kasus meninggal sehingga CFR 1,98\% dan gambaran menurut umur terbanyak pada usia 5-9 tahun dan 1-4 tahun., ${ }^{7,12,14}$ Gambaran perkembangan difteri di Indonesia mulai tahun 20102017 tertera pada Grafik 1.

Sementara gambaran Case Fatality Rate berdasarkan kelompok umur pada tahun 2017 tertera pada Grafik 2.

\section{Manifestasi klinis}

Tergantung pada berbagai faktor, manifestasi penyakit ini bisa bervariasi dari tanpa gejala sampai keadaan berat dan fatal. Sebagai faktor primer adalah imunitas pejamu, virulensi serta toksigenitas $C$. diphteriae (kemampuan kuman membentuk toksin) dan lokasi penyakit secara anatomis. Difteria mempunyai masa tunas 2-6 hari. Berikut ini adalah beberapa jenis difteri menurut lokasinya.

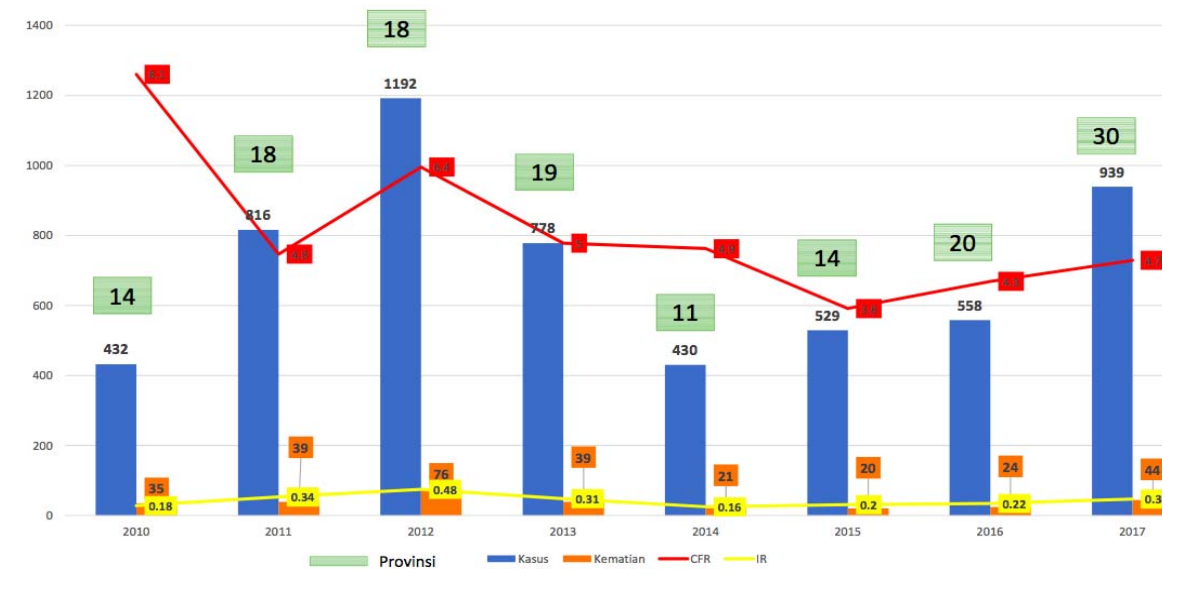

Grafik 1. Perkembangan difteri di Indonesia mulai 2010-2017 


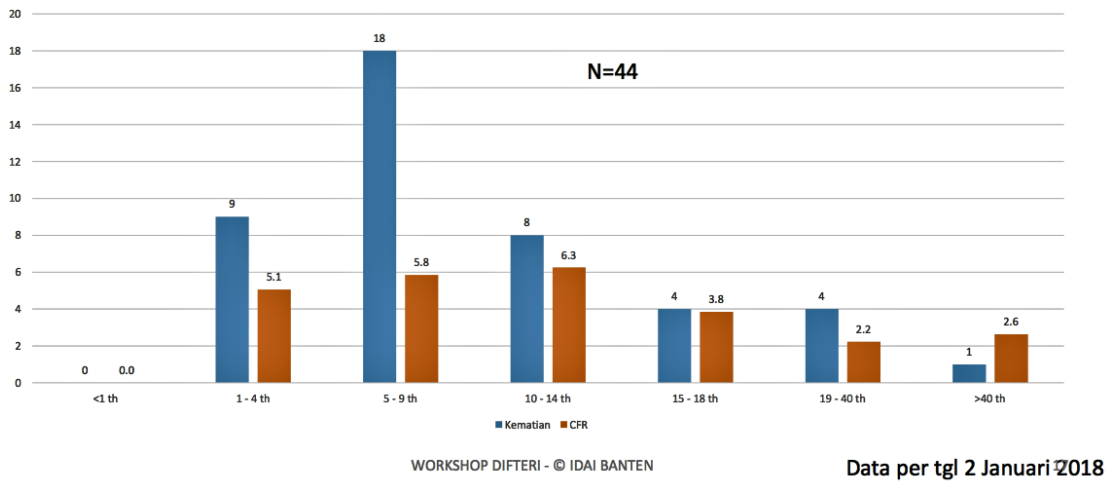

Grafik 2. Case fatality rate berdasarkan kelompok umur

\section{- Difteri saluran napas}

Fokus infeksi primer yang sering, yaitu pada tonsil atau pharynx kemudian hidung dan larynx. Infeksi dari nares anterior lebih sering terjadi pada bayi, menyebabkan sekret serosanguinis, purulen, dan rhinitis erosiva dengan pembentukan membran. Ulkus dangkal dari nares eksternal dan bibir atas merupakan tanda khas. Pada difteria tonsilar dan pharyngeal, sakit tenggorokan merupakan gejala yang pertama kali muncul. Separuh pasien memiliki gejala demam dan sebagian lagi mengeluhkan disfagia, suara serak, malaise atau sakit kepala. Injeksi pharyngeal ringan diikuti dengan pembentukan membran tonsilar baik uni maupun bilateral yang bisa meluas ke uvula (bisa mengakibatkan paralisis yang dimediasi oleh toksin), palatum molle, oropharynx posterior, hypopharynx, atau area glotis. ${ }^{2,4}$

\section{- Difteri hidung}

Difteria hidung pada awalnya menyerupai common cold dengan gejala pilek ringan tanpa atau disertai gejala sistemik ringan. Sekret hidung berangsur menjadi serosanguinus dan kemudian mukopurulen, menyebabkan lecet pada nares dan bibir atas. Pada pemeriksaan tampak membran putih pada daerah septum nasi. Absorpsi toksin sangat lambat dan gejala sistemik yang timbul tidak nyata sehingga diagnosis lambat dibuat.

\section{- Difteri tonsil dan faring}

Gejala difteria tonsil-faring adalah anoreksia, malaise, demam ringan, dan nyeri menelan. Dalam 1-2 hari kemudian timbul membran yang mudah perdarah, melekat, berwarna putih-kelabu dapat menutup tonsil dan dinding faring, meluas ke uvula dan palatum molle atau ke bawah ke laring dan trakea. Dapat terjadi limfadenitis servikalis dan submandibular, bila limfadenitis terjadi bersamaan dengan edema jaringan lunak leher yang luas timbul bullneck. Selanjutnya, gejala tergantung dari derajat penetrasi toksin dan luas membran. Pada kasus berat, dapat terjadi kegagalan pernafasan dan sirkulasi, paralisi palatum molle baik uni maupun bilateral, disertai kesukaran menelan dan regurgitasi. Stupor, koma, kematian bisa terjadi dalam 1 minggu sampai 10 hari.

Pada kasus sedang, penyembuhan terjadi secara berangsur dan bisa disertai penyulit miokarditis atau neuritis. Pada kasus ringan, membran akan terlepas dalam 7-10 hari dan biasanya terjadi penyembuhan sempurna.

\section{- Difteri laring}

Difteria laring biasanya merupakan perluasan difteria faring. Pada difteria laring gejala toksik kurang jika dibandingkan difteri faring karena mukosa laring mempunyai daya serap toksin yang rendah dibandingkan mukosa faring sehingga gejala obstruksi saluran nafas atas lebih mencolok. Gejala klinis difteria laring sukar dibedakan dengan gejala sindrom croup, seperti nafas berbunyi, stridor yang progresif, suara parau dan batuk kering. Pada obstruksi laring yang berat terdapat retraksi suprasternal, interkostal, dan supraklavikular. Bila terjadi pelepasan membran yang menutup jalan nafas bisa terjadi kematian mendadak. Pada kasus berat, membran dapat meluas ke percabangan trakeobronkial. Apabila difteria laring terjadi sebagai perluasan dari difteria faring maka gejala yang tampak merupakan campuran gejala obstruksi dan toksemia. 


\section{- Difteri kulit}

Difteria kulit merupakan infeksi nonprogresif yang ditandai dengan ulkus superfisial, ektima, indolent dengan membran coklat kelabu di atasnya, sulit dibedakan dengan impetigo akibat Stapyllococcus/ Streptococcus dan biasanya bersamaan dengan infeksi kulit ini. Pada banyak kasus infeksi, difteri merupakan infeksi sekunder pada dermatosis, laserasi, luka bakar, tersengat atau impetigo. Ekstremitas lebih sering terkena daripada leher atau kepala. Infeksi simtomatik atau kolonisasi kuman di traktus respiratorius dengan komplikasi toksin terjadi pada sebagian kecil penderita difteria kulit.

\section{- Difteri pada tempat lain}

C. diphteriae dapat menyebabkan infeksi mukokutaneus pada tempat lain, seperti di telinga (otitis eksterna), mata (purulen dan ulseratif konjungtivitis) dan traktus genitalis (purulen dan ulseratif vulvovaginitis). Tanda klinis terdapat ulserasi, pembentukan membran dan perdarahan submukosa membantu dalam membedakan difteria dari penyebab bakteri lain dan virus. Difteria pada mata dengan lesi pada konjungtiva berupa kemerahan, edema dan membran pada konjungtiva palpebra. Pada telinga berupa otitis eksterna dengan sekret purulen dan berbau.

\section{Diagnosis}

Diagnosis difteria ditegakkan berdasarkan pemeriksaan klinis dan laboratorium. Ditemukan kuman difteria dengan pewarnaan Gram secara langsung kurang dapat dipercaya. Cara yang lebih akurat adalah dengan identifikasi secara flourescent antibody technique, tetapi untuk ini diperlukan seorang ahli. Diagnosis pasti dengan isolasi $C$. diphteriae dengan pembiakan pada media Loeffler atau dengan media baru Amies dan Stewart dilanjutkan dengan tes toksinogenitas secara in vivo (marmut) dan in vitro (tes Elek). Beberapa definisi yang dipakai untuk memudahkan dilapangan:

Kasus suspek difteri adalah orang dengan gejala laryngitis, nasofaringitis atau tonsillitis ditambah pseudomembran putih keabuan yang tak mudah lepas dan mudah berdarah di faring, laring, tonsil. Kasus probable difteri adalah suspek difteri ditambah salah satu dari: a) pernah kontak dengan kasus ( $<2$ minggu), b) berasal dari daerah endemis difteri, c) Stridor, bullneck, perdarahan submukosa atau ptekie pada kulit, d) gagal jantung, gagal ginjal akut, miokarditis dan kelumpuhan motorik 1 s/d 6 minggu setelah awitan, e) kematian. Kasus konfirmasi difteri adalah kasus probable yang hasil isolasi ternyata positif C.difteriae toksigenik (dari usap hidung, tenggorok, ulkus kulit, jaringan, konjungtiva, telinga, vagina) atau serum antitoksin meningkat 4 kali lipat atau lebih (hanya bila kedua sampel serum diperoleh sebelum pemberian toksoid difteri atau antitoksin). ${ }^{7}$ Sementara kasus karier adalah orang yang tidak menunjukan gejala klinis, tetapi hasil pemeriksaan laboratorium menunjukan positif $C$. diphtariae.

Diagnosis banding

- Difteria hidung, penyakit yang menyerupai difteria hidung ialah rhinorrhea (common cold, sinusitis, adenoiditis), benda asing dalam hidung, snuffles (lues kongenital).

- Difteria faring, harus dibedakan dengan tonsilitis mebranosa akut yang disebabkan oleh Streptococcus (tonsilitas akut, septic sore throat), mononukleosis infeksiosa, tonsilitis membranosa non-bakterial, tonsilitis herpetika primer, moniliasis, blood dyscrasia, pasca tonsilektomi.

- Difteria laring, gejala difteria laring menyerupai laringitis, dapat menyerupai croup sindroma yang lain, yaitu spasmodic croup, angioneurotik edema pada laring, dan benda asing dalam laring.

- Difteria kulit, perlu dibedakan dengan impetigo dan infeksi kulit yang disebabkan oleh Streptococcus atau Stapyllococcus. ${ }^{4}$

\section{Penyulit}

Penyulit difteria dapat terjadi sebagai akibat inflamasi lokal atau akibat aktivitas eksotoksin. Penyulit difteria dapat dikelompokkan dalam obstruksi jalan nafas, dampak eksotoksin terutama ke otot jantung, saraf dan ginjal, serta infeksi sekunder oleh bakteri lain.

a. Obstruksi jalan nafas, disebabkan oleh tertutupnya jalan nafas oleh membran difteria atau oleh karena edema pada tonsil, faring, daerah submandibular dan servikal.

b. Dampak toksin dampak toksin dapat bermanifestasi pada jantung berupa miokarditis yang dapat terjadi baik pada difteria ringan maupun berat dan biasanya terjadi pada pasien yang terlambat mendapatkan pengobatan antitoksin. Pada umumnya, penyulit atau lebih lambat pada minggu ke-2, tetapi bisa lebih dini pada minggu pertama atau lebih lambat pada minggu ke-6. Manifestasi 
miokarditis dapat berupa takikardia, suara jantung redup, terdengar bising jantung, atau aritmia. Bisa juga terjadi gagal jantung. Kelainan pemeriksaan elektrokardiogram dapat berupa elevasi segmen ST, perpanjangan interval $\mathrm{PR}$, dan heart block.

Penyulit pada saraf biasanya terjadi lambat, bersifat bilateral, terutama mengenai saraf motorik dan sembuh sempurna. Bila terjadi kelumpuhan pada palatum molle pada minggu ke-3, suara menjadi sengau, terjadi regurgitasi nasal, kesukaran menelan. Paralisis otot mata biasanya terjadi pada minggu ke-5, meskipun dapat terjadi antara minggu ke-5 dan ke-7.

Paralisis ekstremitas bersifat bilateral dan simetris disertai hilangnya refleks tendon dalam, peningkatan kadar protein dalam likuor serebrospinal. Paralisis diafragma dapat terjadi pada minggu ke-5 dan ke-7 sebagai akibat neuritis saraf frenikus. Hal ini dapat menyebabkan kematian apabila tidak dibantu dengan ventilator mekanik. Bila terjadi kelumpuhan pada pusat vasomotor dan terjadi hipotensi dan gagal jantung. ${ }^{1,2}$

c. Infeksi sekunder bakteri, setelah era penggunaan antibiotik secara luas, penyulit ini sudah sangat jarang terjadi.

\section{Tatalaksana}

Tujuan pengobatan penderita difteria adalah menginaktivasi toksin yang belum terikat secepatnya, mencegah dan mengusahakan agar penyulit yang terjadi minimal, mengeliminasi $C$. diptheriae untuk mencegah penularan serta mengobati infeksi penyerta dan penyulit difteria.

\section{Umum}

Pasien diisolasi sampai masa akut terlampaui dan biakan hapusan tenggorok negatif 2 kali berturut-turut. Pada umumnya, pasien tetap diisolasi selama 2-3 minggu. Istirahat tirah baring selama kurang lebih 2-3 minggu, pemberian cairan serta diet yang adekuat. Khusus pada difteria laring dijaga agar nafas tetap bebas serta dijaga kelembaban udara dengan menggunakan humidifier. ${ }^{1,2}$

\section{Khusus}

Antitoksin: Anti difteri serum (ADS). Antitoksin harus diberikan segera setelah dibuat diagnosis difteria, dengan pemberian antitoksin pada hari pertama, angka kematian pada penderita kurang dari 1\%. Namun, dengan penundaan lebih dari hari ke- 6 menyebabkan angka kematian ini bisa meningkat sampai 30\%.

Sebelum pemberian ADS harus dilakukan uji kulit atau uji mata terlebih dahulu. Pemberian ADS dapat terjadi reaksi anafilaktik sehingga harus disediakan larutan adrenalin 1:1000 dalam semprit. Uji kulit dilakukan dengan penyuntikan 0,1 mL ADS dakam larutan garam fisiologis 1:1000 secara intrakutan. Hasil positif bila dalam 20 menit trejadi indurasi $>10 \mathrm{~mm}$. Uji mata dilakukan dengan meneteskan 1 tetes larutan serum 1:10 dalam garam fisiologis. Pada mata yang lain diteteskan garam fisiologis. Hasil positif bila dalam 20 menit tampak gejala hiperemis pada konjungtiva bulbi dan lakrimasi. Bila uji kulit atau mata positif, ADS diberikan dengan cara desensitisasi (Besredka). Bila uji hipersensitivitas tersebut di atas negatif, ADS harus diberikan sekaligus secara intravena. Dosis ADS ditentukan secara empiris berdasarkan berat penyakit dan lama sakit, tidak tergantung pada berat badan pasien. Pemberian ADS intravena dalam larutan garam fisiologis atau $100 \mathrm{ml}$ glukosa $5 \%$ dalam 1-2 jam. Pengamatan terhadap kemungkinan efek samping obat/reaksi sakal dilakukan selama pemberian antitoksin dan selama 2 jam berikutnya. Demikian pula perlu dimonitor terjadinya reaksi hipersensitivitas lambat (serum sickness). ${ }^{1,2}$

\section{Antibiotik}

Antibiotik diberikan untuk membunuh bakteri dan menghentikan produksi toksin. Pengobatan untuk difteria digunakan eritromisin $(40-50 \mathrm{mg} / \mathrm{kgBB} / \mathrm{hari}$, dosis terbagi setiap 6 jam PO atau IV, maksimum 2 gram per hari), Penisilin V Oral 125-250 mg, 4 kali sehari, kristal aqueous pensilin G (100.000 - 150.000 $\mathrm{U} / \mathrm{kg} / \mathrm{hari}$, dosis terbagi setiap 6 jam IV atau IM), atau Penisilin prokain (25.000-50.000 IU/kgBB/hari, dosis terbagi setiap 12 jam IM). Terapi diberikan untuk 14 hari. Beberapa pasien dengan difteria kutaneus sembuh dengan terapi 7-10 hari. Eliminasi bakteri harus dibuktikan dengan setidaknya hasil 2 kultur yang negatif dari hidung dan tenggorokan (atau kulit) yang diambil 24 jam setelah terapi selesai. Terapi dengan eritromisin diulang apabila hasil kultur didapatkan C. diphteriae. ${ }^{2,4,5}$

\section{Kortikosteroid}

Belum terdapat persamaan pendapat mengenai kegunaan obat ini pada difteria. Dianjurkan pemberian kortikosteroid pada kasus difteria yang disertai gejala. 
Tabel 1. Dosis ADS menurut lokasi membran dan lama sakit

\begin{tabular}{lcc}
\hline Tipe difteria & Dosis ADS (KI) & Cara pemberian \\
\hline Difteria hidung & 20.000 & Intramuskular \\
Difteria tonsil & 40.000 & Intramuskular atau Intravena \\
Difteria faring & 40.000 & Intramuskular atau Intravena \\
Difteria laring & 40.000 & Intramuskular atau Intravena \\
Kombinasi lokasi di atas & 80.000 & Intravena \\
Difteria + penyulit, bullneck & $80.000-120.000$ & Intravena \\
Terlambat berobat $(>72$ jam $)$, lokasi di mana saja & $80.000-120.000$ & Intravena \\
\hline
\end{tabular}

Tabel 2. Pengobatan terhadap kontak difteria

\begin{tabular}{lll}
\hline Biakan & Uji Schick & Tindakan \\
\hline$(-)$ & $(-)$ & Bebas isolasi: anak yang telah mendapat imunisasi dasar diberikan booster toksoid difteria \\
$(+)$ & $(-)$ & $\begin{array}{l}\text { Pengobatan karier: penisilin } 100 \mathrm{mg} / \mathrm{kgBB} / \mathrm{hari} \text { oral } / \text { suntikan, atau eritromisin } 40 \mathrm{mg} / \mathrm{kgBB} / \\
\text { hari selama } 1 \mathrm{minggu}\end{array}$ \\
$(+)$ & $(+)$ & Penisilin $100 \mathrm{mg} / \mathrm{kgBB} / \mathrm{hari}$ oral $/$ suntikan, atau eritromisin $40 \mathrm{mg} / \mathrm{kgBB}+\mathrm{ADS} 20.000 \mathrm{KI}$ \\
$(-)$ & $(+)$ & Toksoid difteria (imunisasi aktif), sesuaikan dengan status imunisasi
\end{tabular}

- Obstruksi saluran nafas bagian atas (dapat disertai atau tidak bullneck)

- Bila terdapat penyulit miokarditis.

Prednison $2 \mathrm{mg} / \mathrm{kgBB} /$ hari selama 2 minggu kemudian diturunkan dosisnya bertahap.

\section{Pengobatan penyulit}

Pengobatan terutama ditujukan untuk menjaga agar hemodinamika tetap baik. Penyulit yang disebabkan oleh toksin umumnya reversibel. Bila tampak kegelisahan, iritabilitas serta gangguan pernafasan yang progresif merupakan indikasi tindakan trakeostomi. ${ }^{2}$

\section{Pengobatan kontak}

Pada anak yang kontak dengan pasien sebaiknya diisolasi sampai tindakan berikut terlaksana, yaitu biakan hidung dan tenggorok serta gejala klinis diikuti setiap hari sampai masa tunas terlampaui, pemeriksaan serologi dan observasi harian. Anak yang telah mendapat imunisasi dasar diberikan booster toksoid difteria. ${ }^{5,7}$

\section{Pengobatan karier}

Karier adalah mereka yang tidak menunjukkan keluhan, mempunyai uji Schick negatif tetapi mengandung basil difteria dalam nasofaringnya. Pengobatan yang dapat diberikan adalah penisilin $100 \mathrm{mg} / \mathrm{kgBB} / \mathrm{hari}$ oral/iv atau eritromisin $40 \mathrm{mg} / \mathrm{kgBB} /$ hari selama satu minggu. Mungkin diperlukan tindakan tonsilektomi/ adenoidektomi.

\section{Prognosis}

Prognosis difteria setelah ditemukannya ADS dan antibiotik lebih baik daripada sebelumnya. Di Indonesia, pada daerah kantong yang belum di imunisasi, masih dijumpai kasus difteria berat dengan prognosis buruk. Menurut Krugman, kematian mendadak pada kasus difteria dapat disebabkan oleh karena (1) obstruksi jalan nafas mendadak diakibatkan oleh terlepasnya membran difteria, (2) Adanya miokarditis dan gagal jantung, dan (3) paralisis diafragma sebagai akibat neuritis nervus frenikus. Anak yang pernah menderita miokarditis atau neuritis sebagai penyulit difteria, pada umumnya akan sembuh sempurna tanpa gejala sisa, walaupun demikian pernah dilaporkan kelainan jantung yang menetap. ${ }^{1,12,13}$

\section{Pencegahan}

Pencegahan secara umum dengan menjaga kebersihan dan memberikan pengetahuan tentang bahaya difteria bagi anak. Pada umumnya, setelah seorang anak menderita difteria, kekebalan terhadap penyakit ini sangat rendah sehingga perlu imunisasi. Pencegahan secara khusus terdiri dari imunisasi DPT dan pengobatan karier.

Imunitas pasif diperoleh secara transplasental dari ibu yang kebal terhadap difteria sampai 6 bulan dan suntikan antitoksin yang dapat bertahan selama 2-3 minggu. Imunitas aktif diperoleh setelah menderita aktif yang nyata atau inapparent infection serta imuni- 
sasi toksoid difteria. Imunisasi DPT sangat penting untuk mempertahankan kadar antibodi tetap tinggi diatas ambang pencegahan dan imunisasi ulangan sangat diperlukan agar lima kali imunisasi sebelum usia 6 tahun. Imunitas terhadap difteria dapat diukur dengan uji Schick dan uji Moloney. ${ }^{6,7,10,13}$

Apabila belum pernah mendapat DPT, diberikan imunisasi primer DPT tiga kali dengan interval masing-masing 4-6 minggu. Apabila imunisasi belum lengkap segera dilengkapi (lanjutkan dengan imunisasi yang belum diberikan, tidak perlu diulang), dan yang telah lengkap imunisasi primer ( $<1$ tahun) perlu dilakukan imunisasi DPT ulangan umur 18 bulan dan 5 tahun.

- DPT-HB-Hib untuk anak usia $<5$ tahun

- DT untuk anak usia 5 tahun sampai $<7$ tahun

- Td untuk usia 7 tahun keatas

Test kekebalan:

- Schick test: Menentukan kerentanan (suseptibilitas) terhadap difteri. Tes dilakukan dengan menyuntikan toksin difteri (dilemahkan) secara intrakutan. Bila tidak terdapat kekebalan antitoksik akan terjadi nekrosis jaringan sehingga test positif.

- Moloney test : Menentukan sensitivitas terhadap produk kuman difteri. Tes dilakukan dengan memberikan $0,1 \mathrm{ml}$ larutan fluid diphtheri toxoid secara suntikan intradermal. Reaksi positif bila dalam 24 jam timbul eritema $>10 \mathrm{~mm}$. Ini berarti bahwa

- $\quad$ pernah terpapar pada basil difteri sebelumnya sehingga terjadi reaksi hipersensitivitas.

- pemberian toksoid difteri bisa mengakibatkan timbulnya reaksi yang berbahaya. ${ }^{6,8,9}$

\section{Daftar pustaka}

1. Buescher ES. Diphtheria (Corynebacterium diphtheriae). Dalam: Kliegman RM, Stanton BF, St Geme III JW, Schor
NF, penyunting. Nelson Textbook of Pediatrics. Edisi ke-20 Chapter 187. USA: Elsevier; 2016.h.1345-51.

2. Anonim. Difteria pada buku ajar infeksi \& pediatri tropis. Jakarta: Badan Penerbit IDAI;2010.h.312-21.

3. Lubis, Bidasari. Penelitian status imunitas terhadap penyakit difteri dengan schick test pada anak sekolah taman kanakkanak Kotamadya Medan. Diakses pada 9 Februari 2018. Didapat dari: http://library.usu.ac.id/download/fk/anakbidasari3.pdf.

4. Abdul R, Mathilda L, Suharto, Suharno J. Corynebacterium pada Buku Ajar Mikrobiologi Kedokteran. Edisi revisi. Jakarta: Binarupa Aksara;1994.h.128-9.

5. Wharton, Melinda. Diphtheria. Dalam: Gershon AA, Hotez PJ, Katzsl. Krugman's infectious diseases of children. Edisi ke-11. USA: Mosby;2004.h.85.

6. Arifin I, Prasasti C. Faktor yang berhubungan dengan kasus difter anak di Puskesmas Bangkalan Tahun 2016. Jurnal Berkala Epidemiologi 2017;5:26-36.

7. Whitea RO, Thompsonc JR, Rothmand RL, dkk. A health literate approach to the prevention of childhood overweight and obesity. Patient Educ Couns 2013;93:612-8.

8. Mossong J. Putz L. Shkedy Z. Schneider F. Seroepidemiology of diphtheria and pertussis in Luxembourg. Epidemiol Infect 2006;134;573-8

9. Efstratiou A, George RC. Microbiology and epidemiology of diphtheria. Rev Med Microbiol 1997;7:31-42.

10. WHO. Diptheria vaccine WHO position paper. WER. No.3.2006:21-32. Diakses pada 2 Februari 2018. Didapat dari: http://www.who.int/wer/2006/wer8103.pdf.

11. Bjorkholm B, Bottiger M, Christensen B. Antitoxin antibody level and the outcome of illness during outbreak of diphtheria. Scand J Infect Dis 1998;18:235-9

12. Hall AJ. Cassiday PK, Bernad KA, dkk. Isolation of novel Corynebacterium diptheriae from domestics cat. Emerg Infect Dis 2010;16:688-91

13. CDC. Respiratory diphtheria like illness cause bay toxigenic Corynebacterium diptheriae. MMWR 2011;3:60-77.

14. Kemkes RI. Profil kesehatan Indonesia tahun 2015. Diakses pada 2 Februari 2018. Didapat dari: http://www.depkes.go.id/ resources/download/pusdatin/profil-kesehatan-indonesia/profilkesehatan-Indonesia-2015.pdf. 